\title{
Peningkatan Proses dan Hasil Belajar Materi Sistem Persamaan Linier Dua Variabel (SPLDV) Model Pembelajaran Two Stay Two Stray (TSTS) di SMP 3 Bae
}

\section{Eny Kusrini ${ }^{\varpi}$}

SMP 3 Bae Kudus

\section{Info Artikel}

Sejarah Artikel:

Diterima 23 Nov 2020

Direvisi 5 Des 2020

Disetujui 6 Des 2020

Keywords: two stay two stray, learning outcomes and processes

\section{Paper type:}

Research paper

\begin{abstract}
This research is motivated by low attitudes during the learning process and student learning outcomes class VIIIE SMP 3 Bae Kudus. This study aims to determine the increase in attitudes in the process and learning outcomes of class VIIIE students of SMP 3 Bae Kudus on the material of Two-Variable Linear Equation System (SPLDV) by applying the type of Cooperative Learning Model Two Stay Two Stray (TSTS). This type of research is a classroom action research consisting of two cycles. The research was conducted in class VIIIE SMP 3 Bae Kudus. The number of students was 28 consisting of 20 female students and 8 male students. CAR is carried out in two cycles, each of which consists of 4 stages, namely planning, implementing actions, observing and reflecting on the results of the action. From the results of the actions of the attitude of responsibility, cooperation, respect for opinions and self-confidence of students in the first cycle an average of $43 \%$ and increased in the second cycle to $68 \%$. Mean while, student learning outcomes in learning also increased. In the first cycle the student learning outcomes reached an average of 58 with students completing learning as much as $54 \%$ and in the second cycle the student learning outcomes reached an average of 77 with students completing learning as much as $78.6 \%$. The conclusion that can be drawn from this research is the application of the TSTS Type Cooperative learning model can improve student attitudes and learning outcomes in the material of Two Variable Linear Equation Systems in class VIIIE SMP 3 Bae Kudus.
\end{abstract}

\section{Abstrak}

Penelitian ini dilatarbelakangi oleh rendahnya sikap selama proses pembelajaran dan hasil belajar siswa kelas VIIIE SMP 3 Bae Kudus. Penelitian bertujuan untuk mengetahui peningkatan sikap dalam proses dan hasil belajar siswa kelas VIIIE SMP 3 Bae Kudus pada materi Sistem Persamaan Linier Dua Variabel (SPLDV) dengan menerapkan Model Pembelajaran Kooperatif Tipe Two Stay Two Stray (TSTS). Jenis penelitian ini adalah penelitian tindakan kelas yang terdiri atas dua siklus. Penelitian dilaksanakan di kelas VIIIE SMP 3 Bae Kudus. Jumlah siswa 28 orang terdiri 20 orang siswa putri dan 8 orang siswa putra. PTK dilaksanakan dalam dua siklus yang masing-masing terdiri atas 4 tahap yaitu perencanaan, pelaksanaan tindakan, observasi dan refleksi terhadap hasil tindakan. Dari hasil tindakan sikap tanggung jawab, kerja sama, menghargai pendapat dan percaya diri siswa pada siklus I rata-rata mencapai $43 \%$ dan meningkat pada siklus II menjadi $68 \%$. Sementara itu hasil belajar siswa dalam pembelajaran juga mengalami peningkatan. Pada siklus I hasil belajar siswa mencapai rata-rata 58 dengan siswa tuntas belajar sebanyak $54 \%$ dan pada siklus II hasil belajar siswa mencapai rata-rata 77 dengan siswa tuntas belajar sebanyak 78,6\%. Kesimpulan yang dapat diambil dari penelitian ini adalah penerapan model pembelajaran Kooperatif Tipe TSTS dapat meningkatkan sikap dan hasil belajar siswa pada materi Sistem Persamaan Linier Dua Variabel dikelas VIIIE SMP 3 Bae Kudus.

(C) 2020 Universitas Muria Kudus

\footnotetext{
Alamat korespondensi:

Program Studi Pendidikan Matematika

Fakultas Keguruan dan Ilmu Pendidikan Universitas Muria Kudus

Kampus UMK Gondangmanis, Bae Kudus Gd. L. 1t I PO. BOX 53

Kudus

Tlp (0291) 438229 ex.147 Fax. (0291) 437198

E-mail: enykusrinismp3bae@gmail.com
}

p-ISSN 2615-4196

e-ISSN 2615-4072 


\section{PENDAHULUAN}

Lemahnya proses dan hasil belajar matematika salah stau penyebabnya adalah metode yang digunakan guru kurang variatif. Dari proses yang kurang tepat membawa hasil yang kurang optimal. Proses pembelajaran adalah proses yang di dalamnya terdapat kegiatan interaksi antara guru-siswa dan komunikasi timbal balik yang berlangsung dalam situasi edukatif untuk mencapai tujuan belajar (Rustaman, 2001:461). Tujuan pembelajaran menurut Nasution (1998:25) dibagi menjadi tiga kategori yaitu: kognitif (kemampuan intelektual), afektif (perkembangan moral), dan psikomotorik (keterampilan). Hal tersebut akan tercapai jika terdapat keselarasan dalam komponen pembelajaran. Dijelaskan oleh Zain dkk (1997:48) terdapat beberapa komponen pembelajaran yang saling berkaitan antara satu dengan yang lainnya yaitu: 1) guru, 2) siswa, 3) materi pembelajaran, 4) metode pembelajaran, 5) media pembelajaran, 6) evaluasi pembelajaran.

Menurut Salahudin dan Alkrienchie (2017:67), pada dasarnya belajar adalah proses perubahan tingkah laku, meliputi: 1) perubahan pengetahuan, 2) perubahan sikap, 3) perubahan perbuatan, 4) perubahan pemahaman, 5) perubahan keterampilan, 6) perubahan apresiasi.

Dalam pembelajaran terjadi panambahan pengetahuan, dan juga kecakapan, keterampilan, sikap, pengertian harga diri, minat, watak, penyesuaian diri. Penambahan-penambahan dalam pembelajaran tersebut dapat diperoleh saat proses pembelajaran.

Menurut Sardiman (2011:20), belajar diartikan sebagai suatu perubahan tingkah laku karena hasil dari pengalaman yang diperoleh. Belajar adalah proses interaksi antara diri manusia dengan lingkungannya, yang mungkin berwujud pribadi, fakta, konsep atau teori. Dari belajar akan didapatkan perubahan tingkah laku dan hasil belajar itu sendiri.

Nana Sudjana (2005:22) mengatakan hasil belajar adalah kemampuan-kemampuan yang dimiliki siswa setelah ia menerima pengalaman belajarnya. Kemampuan yang dimiliki adalah penguasaan sejumlah pengetahuan dan keterampilan baru serta sikap baru ataupun memperkuat sesuatu yang telah dikuasai sebelumnya, termasuk pemahaman dan penguasaan nilai-nilai.

Belajar mendorong siswa untuk berbuat, sehingga didalam belajar pasti melakukan suatu kegiatan yang akan memberikan hasil dari apa yang sudah dikerjakan, diciptakan baik secara individu maupun kelompok. Keberhasilan proses pembelajaran dapat dilihat dari perubahan sikap dalam kegiatan pembelajaran yang akan berpengaruh pada prestasi yang dicapai siswa.

Hasil belajar merupakan prestasi belajar peserta didik secara keseluruhan yang menjadi indikator kompetensi dasar dan derajad perilaku yang bersangkutan. (Mulyasa, 2009: 212). Untuk meningkatkan hasil belajar guru berusaha menggunakan model pembelajarann yang tepat untuk materi dan karakteristik siswa. Karena pemilihan model pembelajaran yang tepat diyakini dapat meningkatkan hasil belajar siswa. Indikator hasil belajar setiap Kompetensi dasar atau Standar Kompetensi dapat memanfaatkan Kriteria Ketuntasan minimal (KKM).

Persamaan adalah kalimat terbuka yang terdapat hubungan sama dengan. Persamaan linear adalah persamaan yang variabelnya berpangkat satu. Persamaan linear dua variabel adalah persamaan linear yang memiliki dua variabel. Persamaan linear dua variabel dapat dinyatakan dalam bentuk : $a x+b y=c$ dengan $a$, $\mathrm{b}$ dan $\mathrm{c} \in \mathrm{R}$ (bilangan riil), $\mathrm{a}, \mathrm{b} \neq 0$ dan $\mathrm{x}$, y suatu variabel.

Sistem persamaan adalah sebuah himpunan persamaan-persamaan yang melibatkan variabel-variabel yang sama. Sistem persamaan linier dua variable biasa ditulis ax + by $=\mathrm{c}$ dan $\mathrm{dx}+$ ey $=\mathrm{f}$. Penyelesaian dari sistem persamaan linear dua variabel adalah pasangan nilai-nilai pengganti variabel yang membuat persamaan-persamaan dalam sistem tersebut menjadi pernyataan yang bernilai benar.

Ada 3(tiga) cara menyelesaikan SPLDV yaitu cara grafik (penyelesaian SPLDV merupakan titik potong antara kedua garis lurus yang tergambar), substitusi (mengganti, mengganti variabel satu dengan yang lain, dengan diawali menyatakan variabel satu ke variabel lain dalam suatu SPLDV) dan eliminasi (menghilangkan salah satu variabel dengan cara menyamakan koefien salah satu variable kemudian dijumlah/dikurang, sehingga tinggal satu variable saja).

Dalam pembelajaran kooperatif ada enam fase, yaitu penyampaian tujuan, penyajian informasi, membentuk kelompok, kerja kelompok, presentasi hasil, evaluasi dan penghargaan kelompok/individu.

Model pembelajaran Two Stay-Two Stray (Dua Tinggal Dua Tamu) merupakan model pembelajaran kooperatif yang memberi pengalaman kepada siswa untuk berbagi pengetahuan didalam maupun diluar dalam kelompok (Mariyam, 2012). 
TS-TS adalah model pembelajaran yang pada dasarnya adalah variasi diskusi kelompok, dengan ciri khas adanya saling bertamu ke kelompok lain untuk mendiskusikan hasil kelompok asal dengan kelompok tuan rumah.

Menurut Moch. Agus Krisno Budiyanto (2017:152) pembelajaran kooperatif Two Stay Two Stray (TSTS) terdiri beberapa tahapan sebagai berikut:1) Persiapan (guru adalah membuat RPP (Rencana Pelaksanaan Pembelajaran), penilaian, menyiapkan LKS (lembar kerja siswa) dan membagi siswa ke dalam beberapa kelompok dengan masingmasing beranggotakan 4 siswa; 2) Presentasi guru (menjelaskan materi); 3) Kegiatan kelompok; 4) Presentasi kelompok; 5) Evaluasi kelompok dan penghargaan.

Dalam pembelajaran guru tidak hanya melakukan penilaian pengetahuan dan ketrampilan, tetapi sikap siswa saat mengikuti pembelajaran juga masuk dalam penilaian. Penilaian sikap dapat dilakukan dengan observasi atau pengamatan. Dalam penelitian ini sikap yang akan diamati antara lain: a) Tanggung jawab; indikator yang digunakan pada karakter tanggung jawab yaitu:1)Melaksanakan tugas yang diberikan dengan baik, 2) Menyelesaikan tugas tepat waktu. b) Kerja sama : dua siswa atau 1 lebih yang saling berinteraksi, menggabungkan tenaga, ide atau pendapat dalam waktu tertentu dalam mencapai tujuan pembelajaran sebagai kepentingan bersama. Indikator kerja sama yang digunakan dalam penelitian ini adalah;1) Mau bekerja sama dalam kelompok, 2) Mau bekerja sama dengan kelompok lain, 3) Menghargai pendapat orang lain, c) Menghargai pendapat orang lain (menhilangkan sifat egoism); Indikator yang digunakan pada karakter menghargai pendapat orang lain dalam penelitian ini adalah;1) Menyimak saat orang lain berpendapat, 2) Menanggapi pendapat dengan santun, 3) Menghargai pendapat yang berbeda. d) Percaya diri (tingkatan rasa sugesti tertentu yang berkembang dalam diri seseorang sehingga merasa yakin dalam berbuat sesuatu. Indikator percaya diri dalam penelitian ini adalah;1) Berani bertanya, 2) Berani menjawab pertanyaan, 3) Berani memberi pendapat, 4) Berani presentasi didepan kelas.

Berdasarkan kajian pustaka dan kerangka berpikir diatas, maka dapat diajukan hipotesis : 1) Melalui pembelajaran kooperatif tipe $T w o$ Stay Two Stray dapat meningkatkan proses belajar matematika siswa kelas VIII E SMP 3 Bae 2) Melalui pembelajaran kooperatif tipe Two
Stay Two Stray dapat meningkatkan hasil belajar matematika siswa kelas VIII E SMP 3 Bae.

\section{METODE PENELITIAN}

Peneklitian ini terdiri dari dua siklus terbagi dalam enam kali pertemuan, dilakukan di SMP 3 Bae dengan subjek penelitian adalah siswa kelas VIIIE SMP 3 Bae Kudus yang berjumlah 28 siswa, terdiri dari 8 siswa laki-laki dan 20 siswa perempuan. SMP 3 Bae Kudus yang beralamat jalan UMK Gondangmanis Bae Kudus secara geografis termasuk daerah pinggiran di kecamatan Bae.

Teknik pengumpulan data yang digunakan ada 2 yaitu tes (ulangan) dan non tes (observasi). Teknik tes digunakan untuk mengetahui dan mendapatkan data hasil belajar siswa dalam menyelesaikan soal setelah pembelajaran materi menentukan penyelesaian Sistem Persamaan Linier Dua Variabel. Sedangkan teknik Non Tes, data non tes (hasil observasi) digunakan untuk mengetahui perubahan perilaku siswa saat proses pembelajaran yaitu mengetahui sikap siswa dalam pembelajaran.

Sumber data dalam penelitian ini terdiri dari : 1) Sumber Data Primer yaitu data yang diperoleh dari proses belajar mengajar, hasil tes dan jurnal, 2) Sumber Data Sekunder yaitu data yang diperoleh dari kolaborator setelah observasi sikap siswa saat proses belajar mengajar.

Data-data tersebut diperoleh dengan soal tes tes tertulis berbentuk uraian. Sedangkan data non tes menggunakan lembar observasi untuk siswa dalam proses pembelajaran.

Agar data yang diperoleh akurat maka dilakukan tindakan validasi dengan 2 cara. Untuk data kualitatif tentang proses (sikap) divalidasi dengan triangulasi (pengecekan keabsahan data). Untuk data kuantitatif hasil belajar dilakukan dilakukan dengan membuat kisi-kisi soal sebelum soal digunakan.

Dalam penelitian ini data yang terkumpul dianalisis dengan : 1)Data Kualitatif menggunakan analisis deskriptif kualitatif berdasarkan hasil observasi dan refleksi dari tiaptiap siklus, yaitu dengan membandingkan proses pembelajaran kondisi awal dan siklus I, membandingkan pembelajaran dari siklus I dan siklus II, serta membandingkan kondisi awal dan kondisi akhir (siklus II). 2) Data Kuantutatif menggunakan analisis deskriptif komparatif yaitu membandingkan hasil tes pada kondisi awal dan siklus I, membandingkan hasil tes pada siklus I dan siklus II, serta membandingkan kondisi awal dengan kondisi akhir (siklus II). 
Indikator keberhasilan dalam penelitian tindakan kelas ini adalah: 1) Indikator proses belajar : tanggung jawab minimal $75 \%$, kerja sama minimal $75 \%$, menghargai pendapat orang lain minimal $75 \%$, percaya diri minimal $30 \%, 2$ ) Indikator peningkatan hasil belajar yaitu minimal $65 \%$ siswa memperoleh nilai tes minimal sama dengan KKM (Kriteria Ketuntasan Minimal), untuk mata pelajaran Matematika kelas VIII yaitu $67,0$.

Metode penelitian ini menggunakan metode Penelitian Tindakan Kelas yang terdiri dari enam kegiatan yang dilakukan dalam siklus berulang, dimana tiap siklus terdiri dari 3 pertemuan. Tiap siklus terdiri dari 4 tahapan, yaitu Planning (perencanaan), Acting (tindakan), Observing (observasi), Reflecting (refleksi).

Apabila digambarkan, akan tampak sketsa alur pelaksanaan penelitian tindakan kelas ini seperti berikut:

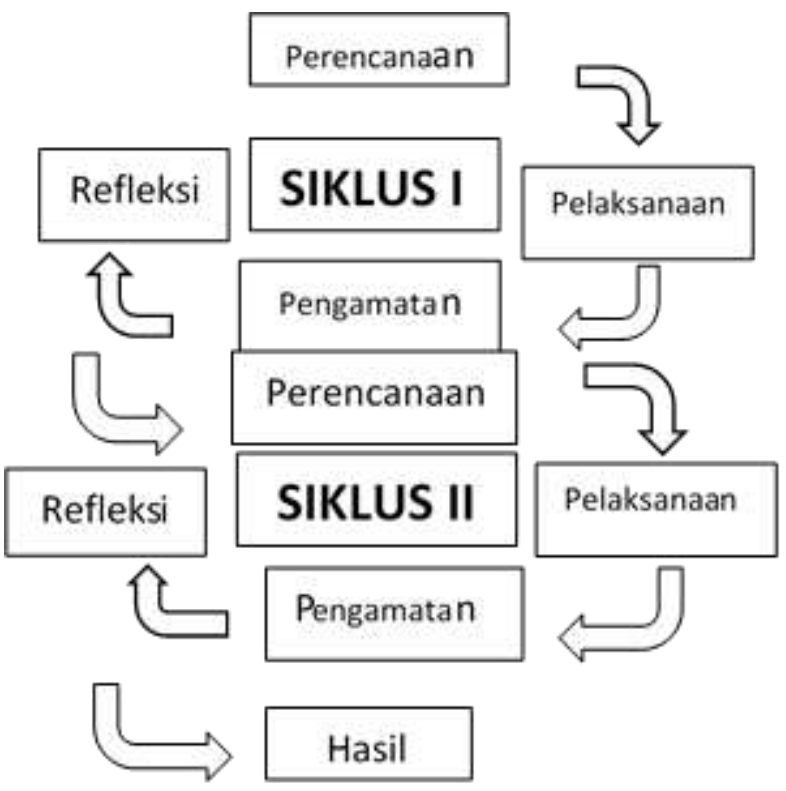

Gambar 1. Alur Penelitian Tindakan Kelas

Tahap perencanaan. Pada tahap ini peneliti melakukan persiapan-persiapan kegiatan mengajar, antara lain: a) menyusun skenario pembelajaran menggunakan model TSTS (RPP dan bahan ajar pertemuan 1, 2 dan 3), b) menyiapkan alat bantu belajar berupa lembar kerja, c) menyusun alat evaluasi, d) menyusun dan menyiapkan lembar observasi pelaksanaan tindakan.

Pelaksanaan dilakukan sesuai skenario yang ada di RPP, dimulai dengan penyampaian materi dari guru, siswa berdiskusi dan menyelesaikan LK yang sudah disiapkan di dalam kelompoknya, presentasi dan evaluasi.
Pengamatan atau observasi pelaksanaan tindakan dilakukan secara kolaboratif antara peneliti dan kolaborator dengan menggunakan lembar observasi pada saat proses pembelajaran berlangsung. Evaluasi hasil pembelajaran juga dilaksanakan secara kolaboratif dengan mengolah data yang telah diperoleh dan menentukan keberhasilan tindakan yang telah dilaksanakan. Aspek yang diamati yaitu pengamatan terhadap sikap siswa dalam proses pembelajaran dengan lembar observasi siswa.

Reflfeksi dilaksanakan setelah siklus I. Hasil observasi dan evaluasi guru sebagai peneliti bersama kolaborator, digunakan sebagai acuan perencanaan dan tindakan pada pemebelajaran siklus II.

\section{HASIL DAN PEMBAHASAN}

Berdasarkan pengamatan pada 28 siswa kelas VIIIE SMP 3 Bae Kudus yang dicatat pada buku jurnal mengajar indikator proses belajar yang diamati adalah sikap saat kegiatan belajar mengajar yaitu tanggung jawab, kerja sama, menghargai pendapat orang lain dan percaya diri dalam mengerjakan tugas kelompok maupun individu diperoleh skor 91 dari jumlah skor seluruhnya 308. Hal ini menunjukkan bahwa karakter siswa dilihat dari 4 sikap di atas dalam pembelajaran materi Persamaan Garis Lurus siswa kelas VIIIE SMP 3 Bae Kudus semester I tahun 2019/2020 masih rendah.

Hasil pengamatan sikap siswa pada proses pembalajaran SPLDV pada siklus I, didapat diperoleh hasil bahwa dari total skor sikap tanggung jawab 168 capaian siswa hanya $28 \%$, sikap kerjasama $29 \%$ dari total skor 168 , sikap menghargai pendapat orang lain $22 \%$ dari total skor 254 dan percaya diri $13 \%$ dari total skor 336. Dari data tersebut sikap siswa dalam proses belajar masuk kategori sedang.

Hasil pengamatan sikap saat belajar menyelesaian SPLDV pada siklus II diperoleh skor tanggung jawab 158 dari skor total 168 atau 94\%, skor kerja sama 159 dari skor total 168 atau $95 \%$, skor menghargai pendapat 193 dari skor total 254 atau 75\%, dan skor percaya diri 116 dari skor total 336 atau 35\%, termasuk kategori tinggi.

Tabel 1. Sikap siswa pada kondisi awal, siklus I dan siklus II

\begin{tabular}{lllcc}
\hline No & Sikap & $\begin{array}{c}\text { Kondisi } \\
\text { Awal }\end{array}$ & $\begin{array}{c}\text { Siklus } \\
\text { I }\end{array}$ & $\begin{array}{c}\text { Siklus } \\
\text { II }\end{array}$ \\
\hline 1 & $\begin{array}{l}\text { Tanggun } \\
\text { g jawab }\end{array}$ & 25 & 109 & 158 \\
2 & $\begin{array}{l}\text { Kerja } \\
\text { sama }\end{array}$ & 30 & 107 & 159 \\
\hline
\end{tabular}




\begin{tabular}{lllll}
\hline No & Sikap & $\begin{array}{c}\text { Kondisi } \\
\text { Awal }\end{array}$ & $\begin{array}{c}\text { Siklus } \\
\text { I }\end{array}$ & $\begin{array}{c}\text { Siklus } \\
\text { II }\end{array}$ \\
\hline 3 & $\begin{array}{l}\text { Menghar } \\
\text { gai } \\
\text { pendapat }\end{array}$ & 21 & 114 & 193 \\
4 & $\begin{array}{l}\text { Percaya } \\
\text { Diri }\end{array}$ & 15 & 68 & 116 \\
& $\begin{array}{l}\text { Jumlah skor } \\
\text { pengamatan }\end{array}$ & $\begin{array}{l}\text { (rendah) } \\
\text { (redan }\end{array}$ & $\begin{array}{l}\text { (sedan } \\
\text { g) }\end{array}$ & $\begin{array}{l}626 \\
\text { (tinggi }\end{array}$ \\
\hline
\end{tabular}

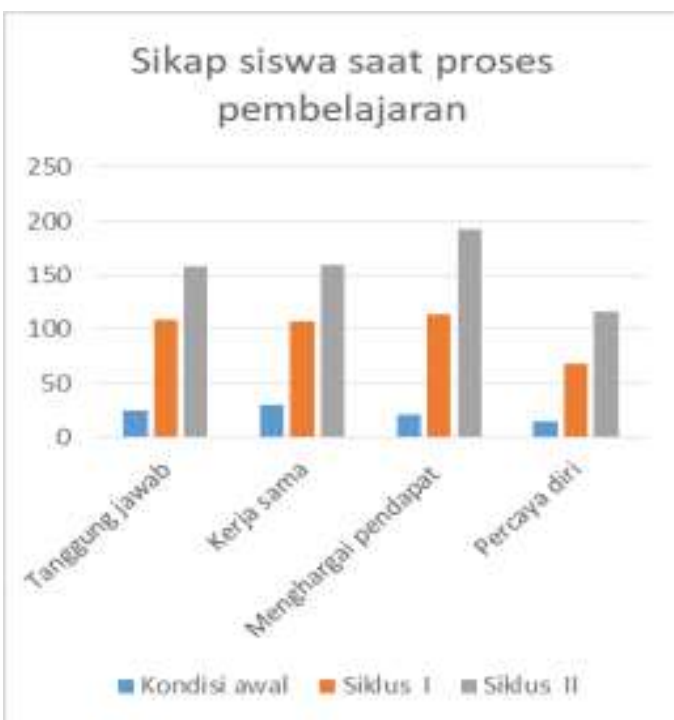

Gambar 2. Grafik hasil pengamatan sikap siswa saat proses pembelajaran

Berdasarkan hasil penilaian materi Persamaan garis lurus, siswa kelas VIIIE SMP 3 Bae Kudus semester I tahun 2019/2020 juga menunjukkan hasil belajar yang rendah. Nilai rata-rata ulangan materi Persamaan Garis Lurus hanya sebesar 54 masih dibawah KKM yaitu 67. Dari 28 siswa masih terdapat 19 siswa yang mendapat nilai dibawah KKM dan 9 siswa yang mendapat nilai sama dengan atau lebih dari KKM. Ini berarti pada kondisi awal hanya $32 \%$ siswa yang tuntas dalam pembelajaran. Dengan nilai terendah 16 , nilai tertinggi 90 , nilai ratarata 54 , rentang 74 .

Sedang hasil penilaian pada siklus I dari 28 siswa terdapat 15 siswa yang tuntas belajar atau nilainya sudah memenuhi nilai KKM sebesar 67. Ini berarti 54\% siswa tuntas belajar. Berdasarkan penilaian pada siklus I diperoleh nilai terendah 18 , nilai tertinggi 100 , nilai ratarata 58 , rentang nilai 82 .

Dari hasil penilaian pada siklus II didapat hasil bahwa dari 28 siswa terdapat 22 siswa yang tuntas belajar atau mendapat nilai memenuhi KKM sebesar 67. Ini berarti ada $78,6 \%$ siswa yang tuntas belajar. Berdasarkan penilaian pada siklus II didapat nilai terendah sebesar 20, nilai tertinggi 100 , nilai rata-rata 77 , rentang nilai 80 .

Tabel 2 Hasil belajar kondisi awal, siklus I dan siklus II

\begin{tabular}{lllll}
\hline No & Uraian & $\begin{array}{c}\text { Kondisi } \\
\text { Awal }\end{array}$ & $\begin{array}{c}\text { Siklus } \\
\text { I }\end{array}$ & $\begin{array}{c}\text { Siklus } \\
\text { II }\end{array}$ \\
\hline 1 & $\begin{array}{l}\text { Nilai } \\
\text { Terendah }\end{array}$ & 16 & 18 & 20 \\
2 & $\begin{array}{l}\text { Nilai } \\
\text { Tertinggi }\end{array}$ & 90 & 100 & 100 \\
3 & $\begin{array}{l}\text { Nilai rata- } \\
\text { rata }\end{array}$ & 54 & 58 & 77 \\
4 & $\begin{array}{l}\text { Nilai lebih } \\
\text { dari KKM }\end{array}$ & 9 & 15 & 22 \\
5 & $\begin{array}{l}\text { Persentase } \\
\text { nilai lebih } \\
\text { dari KKM }\end{array}$ & $32 \%$ & $54 \%$ & $78,6 \%$ \\
\hline
\end{tabular}

Perbandingan hasil belajar kondisi awal, siklus I dan siklus II dapat dilihat pada diagram berikut:

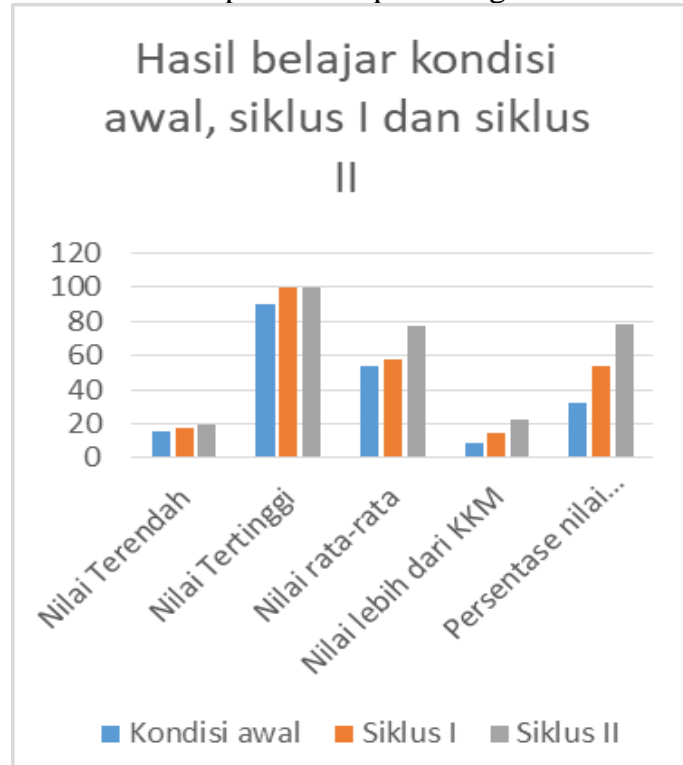

Gambar 3. Grafik hasil belajar kondisi awal, siklus I dan siklus II

Dengan demikian, hipotesis yang menyatakan melaui pembelajaran kooperatif tipe Two Stay Two Stray dapat meningkatkan proses dan hasil belajar matematika siswa kelas VIII E SMP 3 Bae terbukti.

\section{SIMPULAN}

Berdasarkan hasil pembahasan, dapat diambil simpulan sebagai bahwa; 1) Model pembelajaran kooperatif tipe TSTS dapat meningkatkan proses belajar dalam materi penyelesaian SPLDV bagi siswa kelas VIIIE SMP 3 Bae Kudus semester 1 tahun pelajaran 
2019/2020 dari kondisi awal proses belajar diperoleh capaian skor 9,8\% ke kondisi akhir skor mencapai $67,6 \%$ meningkat sebesar $57,8 \%$, 2) model pembelajaran kooperatif tipe TSTS dapat meningkatkan hasil belajar dalam materi penyelesaian SPLDV bagi siswa kelas VIIIE SMP 3 Bae Kudus semester 1 tahun pelajaran 2019/2020 dari kondisi awal hasil belajar nilai rata-rata 54 ke kondisi akhir nilai rata-rata 77 meningkat sebesar 23 poin.

\section{DAFTAR PUSTAKA}

Budiyanto, Agus Krisno. 2016. Sintaks 45 Model Pembelajaran dalam Student Centered Laerning $(S C L)$. Malang : Universitas Muhammadiyah Malang Press.

Mulyasa. 2012. Praktik Penelitian Tindakan Kelas. Bandung: PT Rosdakarya.

Nasution. 1998. Metodologi Penelitian Kualitatif. Bandung:Tarsito.

Rustaman. 2014. Model-model Pembelajaran Mengembangkan Profesionalisme Guru. Jakarta : PT Raja Grafindo Persada.

Salahudin, Anas. dan Irwanto Alkrienciehie. 2013. Pendidikan Karakter(Pendidikan berbasis Agama dan Budaya Bangsa). Bandung:CV Pustaka Setia.

Sudjana, Nana. 2005. Penilaian Hasil Proses Belajar Mengajar. Bandung : Remaja Rosdakarya.

Sardiman. 2011. Interaksi dan Motivasi BelajarMengajar. Jakarta: PT RajaGrafindo Persada.

Zain dkk. 1997. Strategi Belajar Mengajar. Jakarta:Rineka Cipta 